\title{
Antiplasmodial Activity and Phytochemical Constituents of Selected Antimalarial Plants Used by Native People in West Timor Indonesia
}

\section{Batı Timor Endonezya Yerel Halkının Kullandığı Bazı Antimalaryal Bitkilerin Antiplazmodiyal Aktiviteleri ve Fitokimyasal Bileşenleri}

\author{
(D) Maximus M. TAEK ${ }^{1 *}$, (D) Gerardus D. TUKAN1, (D) Bambang E.W. PRAJOGO22, (D) Mangestuti AGIL2 \\ 1Widya Mandira Catholic University Faculty of Mathematics and Natural Sciences, Department of Chemistry, Kupang, Indonesia \\ 2Airlangga University Faculty of Pharmacy, Department of Pharmacognosy and Phytochemistry, Surabaya, Indonesia
}

\begin{abstract}
Objectives: To document traditional antimalarial plants used by Tetun ethnic people in West Timor Indonesia and evaluate the antiplasmodial activity and phytochemicals of several plants that are widely used as oral medicine.

Materials and Methods: A field study to document antimalarial plants followed by laboratory works to test antiplasmodial activity and identify the phytochemical constituents of some selected plants extract were applied. The inhibitory potency of ethanolic extracts of Strychnos ligustrina wood, roots of Calotropis gigantea, Fatuoa pilosa, and Neoalsomitra podagrica, whole plant of Cleome rutidosperma and Physalis angulata, stem barks of Alstonia spectabilis, Alstonia scholaris, Jatropha curcas and Plumeria alba, and leaves of Melia azedarach on the Plasmodium falciparum 3D7 strain in vitro were tested. Gas chromatography-mass spectrometry instrument was used to analyze the phytochemicals of the extracts.

Results: The Tetun ethnic people use 50 plant species as antimalarials. $P$. angulata, J. curcas, and $A$. spectabilis extracts show strong antiplasmodial activity with $\mathrm{IC}_{50}$ values of $0.22,0.22$, and $1.23 \mu \mathrm{g} / \mathrm{mL}$, respectively; $N$. podagrica, $A$. scholaris, $F$. pilosa, and $P$. alba were moderate antiplasmodials with $I_{50}$ values of $11.60,15.46,24.92$, and $36.39 \mu \mathrm{g} / \mathrm{mL}$, respectively; and C. rutidosperma, M. azedarach, S. ligustrina, and C. gigantea were weak antiplasmodials with $\mathrm{IC}_{50}$ values of $54.25,63.52,63.91$, and $66.49 \mu \mathrm{g} / \mathrm{mL}$, respectively. The phytochemicals identification data indicate that these 11 plants contain alkaloids, terpenoids, steroids, coumarins, alcohols, thiols, phenolics, aldehydes, fatty acids, esters, and so forth.

Conclusion: Plants widely used as antimalarials by the Tetun ethnic people is proven to have antiplasmodial activity.
\end{abstract}

Key words: Ethnomedicine, medicinal plant, malaria, antiplasmodial activity

öz

Amaç: Endonezya Batı Timor'unda Tetun etnik halkı tarafından kullanılan geleneksel antimalaryal bitkileri, yaygın oral ilaçlar olarak kullanılan bazı bitkilerin antiplazmodial aktivitelerini ve fitokimyasallarını belirlemek.

Gereç ve Yöntemler: Antimalaryal bitkileri belirleyen alan çalışmasını takiben, antiplazmodiyal aktiviteyi test etmek ve seçilen bitki ekstraktlarından fitokimyasal bileșenleri belirlemek için laboratuvar çalıșması yapılmıștır. Strychnos ligustrina bitkisinin odunsu kısımları, Calotropis gigantea, Fatuoa pilosa ve Neoalsomitra podagrica bitkilerinin kökleri, Cleome rutidosperma ve Physalis angulata bitkilerinin tamamı, Alstonia spectabilis, Alstonia scholaris, Jatropha curcas ve Plumeria alba bitkilerinin gövde kabukları ile Melia azedarach yaprakları etanol ekstrelerinin inhibitör potansiyelleri Plasmodium falciparum 3D7 sușunda in vitro koșullarda belirlendi. Ekstrelerin fitokimyasal içerikleri gaz kromatografisi-kütle spektrometresi ile analiz edildi.

Bulgular: Tetun etnik halkının antimalaryal olarak kullandığı 50 bitki türü olduğu belirlendi. $P$. angulata, J. curcas ve $A$. spectabilis ekstreleri, sırasıyla $0,22,0,22$ ve $1,23 \mathrm{\mu g} / \mathrm{mL} I C_{50}$ değerleriyle güçlü antiplazmodiyal aktivite gösterirken, $N$. podagrica, A. scholaris, F. pilosa ve $P$. alba, sırasıyla 1,60, $15,46,24,92$ ve $36,39 \mu \mathrm{g} / \mathrm{mL} \mathrm{IC}_{50}$ değerleriyle, ve C. rutidosperma, M. azedarach, S. ligustrina ve C. gigantea, sırasıyla 54,25, 63,52, 6391 ve 66,49 $\mu \mathrm{g} / \mathrm{mL} \mathrm{IC}_{50}$ değerleriyle zayıf antiplazmodiyal aktivite gösterdi. Fitokimyasal tanımlamanın verileri, bu 11 bitkinin alkaloitler, terpenoidler, steroidler, kumarinler, alkoller, tiyoller, fenolikler, aldehitler, yağ asitleri, esterler ve diğer bileșikleri içerdiğini gösterdi.

Sonuç: Tetun etnik halkı tarafından yaygın olarak antimalaryal olarak kullanılan bitkilerin antiplazmodiyal aktivite gösterdiği kanıtlanmıştır. Anahtar kelimeler: Etnotıp, şifalı bitki, sıtma, antiplazmodiyal aktivite

*Correspondence: maximusmt2012@gmail.com, Phone: +6282245811193 ORCID-ID: orcid.org/0000-0002-4597-2167

Received: 22.10.2019 Accepted: 26.12.2019

๑Turk J Pharm Sci, Published by Galenos Publishing House. 


\section{INTRODUCTION}

Plants are very valuable source in obtaining various pharmacological active substances to deal with various human health problems.' It has been the basis and an important part of various traditional medical systems for thousands of years. It is estimated that around $25 \%$ or $40,000-70,000$ of the total number of plant species known today are used as medicinal plants in various places all over the world. ${ }^{2,3}$

More recently, natural product chemicals isolated from plants have been a good source of lead compounds used to treat various infectious diseases, including malaria. Two examples of phenomenal lead compounds that have greatly contributed in reducing malaria deaths worldwide are quinine isolated from Cinchona sp. stem bark and artemisinin from Chinese medicinal plants Artemisia annua. ${ }^{4}$ Derivatives such as chloroquine, amodiaquine, primaquine, and mefloquine have been synthesized from quinine; and compounds such as artemether, arteether, and sodium artesunate have been produced from artemisinin. However, Plasmodium has shown in the last few decades increasing resistance to antimalarial quinine derivatives, especially chloroquine, which made them no longer effective. Plasmodium falciparum has also showed an increase in resistance to artemisinin-based antimalarials as reported in several recent publications. ${ }^{5}$

Plasmodium's increasing resistance to currently used antimalarial drugs encouraged researchers to continue searching for new and more effective antimalarials. ${ }^{6}$ Plants have become one of the most important sources in searching new potential antimalarials in traditional medicine of various ethnics worldwide. ${ }^{7}$ A promising and better approach in finding new antimalarial(s) is selecting plants that have been traditionally used in treating malaria. With this, resources such as high investment and skills are saved, and the time of plant selection and testing of its antimalarial activity is shown to be accelerated compared with the random selection approach. For the development of important active antimalarials, research on medicinal plants of various traditional medicine systems could provide useful leads. $^{8}$

The experience of the Tetun people, a native ethnic in West Timor, in interacting with malaria for a long time led to them to develop their own methods of treatment. They identified malaria as sick of hot body or fever. A variety of medicinal plant formula called ai tahan or kwa were carried out by the Tetun community as a traditional treatment for malaria, which is applied by drinking, bathing, massage, inhaling, and cataplasm. ${ }^{9}$ In-depth exploration of the antimalarial plants used in the community's traditional medicine might provide a valuable contribution in discovering new sources of antimalarial substances.

This research is an ethnomedicine study that was first conducted in the Tetun community. In our study, two research steps were performed. For the first step, a field research was conducted to document various species of medicinal plants and formula of traditional medicines for oral treatment of malaria used by the Tetun people. In the second step, some of the high-frequency mentioned plants were selected to test their antiplasmodial activity. In vitro antiplasmodial activity testing was carried out against the chloroquine-sensitive $P$. falciparum 3D7 strain.

\section{MATERIALS AND METHODS}

\section{Field study}

The field research was carried out in several subdistricts of Belu ( $9^{\circ} 15,0$ S, $124^{\circ} 40$ E) and Malaka Districts ( $9^{\circ} 34$ S, $124^{\circ} 54$ E). These two districts are located along the borderline of East Nusa Tenggara Province (Indonesia) and the Republic Democratic de Timor Leste. In this field study, information was collected through interviews and discussions. This study consists of 94 informants, 42 males and 52 females, who were traditional healers, former malaria patients that have undergone traditional medicine, and others who have knowledge and experience in the traditional treatment of malaria. These informants were between the ages of 40 and 90 years old, and almost all of them have settled in their area since they were born.

Data collected on traditional medicinal plants used for malaria treatment include: the plant's local name, place where the plant was obtained, part of the plant used as a medicine, methods of processing and usage, dosage and duration of use, and the medication's claimed effect. To prepare an herbarium, the plants mentioned by the informants were then collected in parts. First, all plants were identified by matching their local name with the scientific names of the species listed in the Timorese local plants book. ${ }^{10}$ Second, experts from the Lembaga Ilmu Pengetahuan Indonesia-Bogor Botanic Garden identified the plants again. Part(s) of some plants mentioned by the informants with high frequency were collected in greater quantities for laboratory evaluation of their antimalarial activity and phytochemicals identification. Those plant part samples were collected from the area where the plant was mentioned.

\section{Preparation of the plant extract}

The attached dirt on the plant part samples, that is the whole plant, stem bark, wood, roots, and leaves, were cleaned using tap water. They were then air-dried at room temperature until they were completely dry and then grounded into powder. The extracts were prepared by maceration. Plant powder of $20 \mathrm{~g}$ each was macerated with 95\% ethanol for $24 \mathrm{~h}$ at room temperature and then filtered. Maceration was repeated three times, and the filtrates were collected and then evaporated to dry using a vacuum rotary evaporator at $40^{\circ} \mathrm{C}$. The dried extracts were stored in a closed container, and were then used for antiplasmodial activity test against $P$. falciparum and phytochemical analysis.

\section{In vitro antiplasmodial activity test}

In vitro antimalarial activity testing was carried out on the chloroquine-sensitive 3D7 strain of $P$. falciparum obtained from the Institute of Tropical Diseases Airlangga University, Surabaya Indonesia. In 96 microwells plate, Plasmodium was cultivated according to a method developed by Trager and Jenssen. ${ }^{11}$ It was carried out using 0 type human red blood cells (RBC) with 5\% hematocrit suspended in RPMl 1640 medium. 
In a $\mathrm{CO}_{2}$ incubator, the culture was incubated at $37^{\circ} \mathrm{C}$, and the medium was replaced every day until parasitemia reaches $1 \%$ $2 \%$. Dried plant extracts were dissolved in dimethylsulphoxide and filtered through a $0.22 \mu \mathrm{m}$ membrane filter. The solution of each extract was then placed in microwells containing Plasmodium suspension with $1 \%$ parasitemia. To obtain the final concentrations of $100,10,1.0,0.1$, and $0.01 \mu \mathrm{g} / \mathrm{mL}$, the solutions were diluted in a series of tenfold dilution with the RPMI 1640 medium. Two series of controls were set up: as a positive control, in which parasitized blood cells without the addition of plant extract; and as a positive control where parasitized blood cells were added with chloroquine diphosphates. To make final concentrations of $100,10,1.0,0.1$, and $0.01 \mu \mathrm{g} / \mathrm{mL}$, preparation for chloroquine diphosphates were similar to plant extracts. The culture was then incubated at $37^{\circ} \mathrm{C}$ in a $\mathrm{CO}_{2}$ incubator for $48 \mathrm{~h}$. Duplicate tests were performed. RBC culture was harvested after $48 \mathrm{~h}$ of incubation. On a glass object, a thin blood was smeared, dried and fixed with methanol, and stained with Giemsa. A light microscope with 1000x magnification was then used to count the number of parasitized RBC.

\section{Statistical analysis}

A total of 1000 s RBC was counted by observing blood smear slides under a microscope, and the number of infected RBC (iRBC) was obtained from the antiplasmodial activity test. The amount of $\mathrm{iRBC}$ to the total RBC was expressed as percentage of parasitemia, which was calculated using the numerical formula as follows:

Percentage of parasitemia, $\mathrm{p}=\left[\left(\sum \mathrm{i} \mathrm{RBC} / \Sigma \mathrm{RBC}\right) \times 100 \%\right]$.

From the percentage of parasitemia data in treated groups and negative control, Plasmodium's growth and inhibition percentages were calculated as follows:

Percentage of growth: (Pt/Pnc) x100\%,

Percentage of inhibition: $100 \%$ - percentage of growth,

where $P t$ is the percentage of parasitemia in treated groups and $P n c$ is the percentage of parasitemia in the negative control group. Pt and Pnc were calculated at the beginning of test $\left(0 \mathrm{~h}, \mathrm{P}_{0}\right)$ and when the culture was harvested $\left(48 \mathrm{~h}, \mathrm{P}_{48}\right)$. The parasitemia's actual percentage value was $P_{48}-P_{0}$. The inhibition percentage range is $0 \%$, which means no inhibition, to $100 \%$, which is complete inhibition.

Probit analysis was used to statistically calculate the 50\% inhibitory concentration $\left(\mathrm{IC}_{50}\right)$ by plotting the data on inhibition percentage versus concentration of each extract. To classify the antimalarial potency of each extract, the $I_{50}$ value was compared with the value given by the literature.

\section{Identification of phytochemicals in extracts}

Gas chromatography-mass spectrometry (GC-MS) was used to analyze the phytochemicals contained in each extract. An Agilent 6980N Network GC system with autosampler was linked to a detector of Agilent 5973 inert MSD. A column of $\mathrm{J}$ and W Scientific HP-5MS $30 \mathrm{~m} \times 0.25 \mathrm{~mm} \times 0.25 \mu \mathrm{m}$ was used. To interpret the compounds, the GC-MS instrument used a Wiley version 7.0 database. The GC-MS operational conditions were set up as follows: Inlet temperature of $250^{\circ} \mathrm{C}$; and oven temperature programmed at $50^{\circ} \mathrm{C}$ for $5 \mathrm{~min}$ and increased to $10^{\circ} \mathrm{C} / \mathrm{min}$ up to $280^{\circ} \mathrm{C}$, maintained constant for $15 \mathrm{~min}$. Temperatures of Aux, MS Quad, and MS Source were $250^{\circ} \mathrm{C}$, $150^{\circ} \mathrm{C}$, and $230^{\circ} \mathrm{C}$, respectively. Used as sample carrier was helium gas with $99.999 \%$ purity. Gas flow in the column was set constant at $1.0 \mathrm{~mL} / \mathrm{min}$ for 50 min running time. Scan mode ranged from 20 amu to 600 amu.

Each extract was first dissolved in $5 \mathrm{~mL}$ ethanol, sonicated for $15 \mathrm{~min}$, and filtered through a $0.45-\mu \mathrm{m}$ nylon membrane filter before running the analysis of the chemical content. The filtrate of $0.2 \mu \mathrm{L}$ was then injected into the GC-MS system. The results were printed out after the analysis process in the instrument was finished.

\section{Ethics committee approval statement}

All field research designs have been approved by the Government of East Nusa Tenggara Province (no: 070/535/DPM-PTSP/2017 and no: 070/535/DPM-PTSP/2017, dated February 28, 2017), the Government of Malaka District (no: 070/150/IV/2017, dated March 3, 2017), and the Government of Belu District (no: BKBP070/75/III/2017, dated March 29, 2017) to guarantee the ethics and legality of human involvement in this study.

\section{RESULTS AND DISCUSSION}

\section{Plants used for malaria treatment}

Documented in this study are 50 plant species belonging to 27 families that used by the Tetun ethnic group for malaria treatment in the Malaka and Belu Districts (Table 1). These plants were used as single formula or combination of plants in various recipes for oral application. Some of the plants that are most frequently mentioned by the informants are Strychnos ligustrina Blume, Calotropis gigantea (L.) R. Br., Cleome rutidosperma DC., Physalis angulata L., Carica papaya L., Alstonia spectabilis R.Br., Alstonia scholaris (L.) R. Br., Melia azedarach L., Plumeria alba L., Swietenia macrophylla King, and Momordica balsamina L.

The highest number of plant species belong to seven families: Apocynaceae and Fabaceae (five species each), Cucurbitaceae (four species), and Meliaceae, Moraceae, Euphorbiaceae, and Rubiaceae (three species each). The most widely used plant parts in its utilization as medicinal materials are the stem bark (21 species), leaves (19 species), and root (11 species). Some plants are used more than one part at a time. Decoction and infusion are the common preparation modes of various formula for oral use of these plants.

Plant selection for antiplasmodial activity test

For antiplasmodial activity testing, 11 plants species with high citation frequency were selected. These are S. ligustrina Blume (34.04\%), C. gigantea (L.) R. Br. (24.47\%), C. rutidosperma DC. (18.09\%), P. angulata L. (18.09\%), A. spectabilis R. Br. (17.02\%), A. scholaris (L.) R. Br. (13.83\%), M. azedarach L. (13.83\%), Fatoua pilosa Gaudich. (7.45\%), Jatropha curcas (6.38\%), P. alba L. (6.38\%), and Neoalsomitra podagrica Steenis (4.26\%). 
Table 1. Plants used by the Tetun ethnic people for malaria treatment

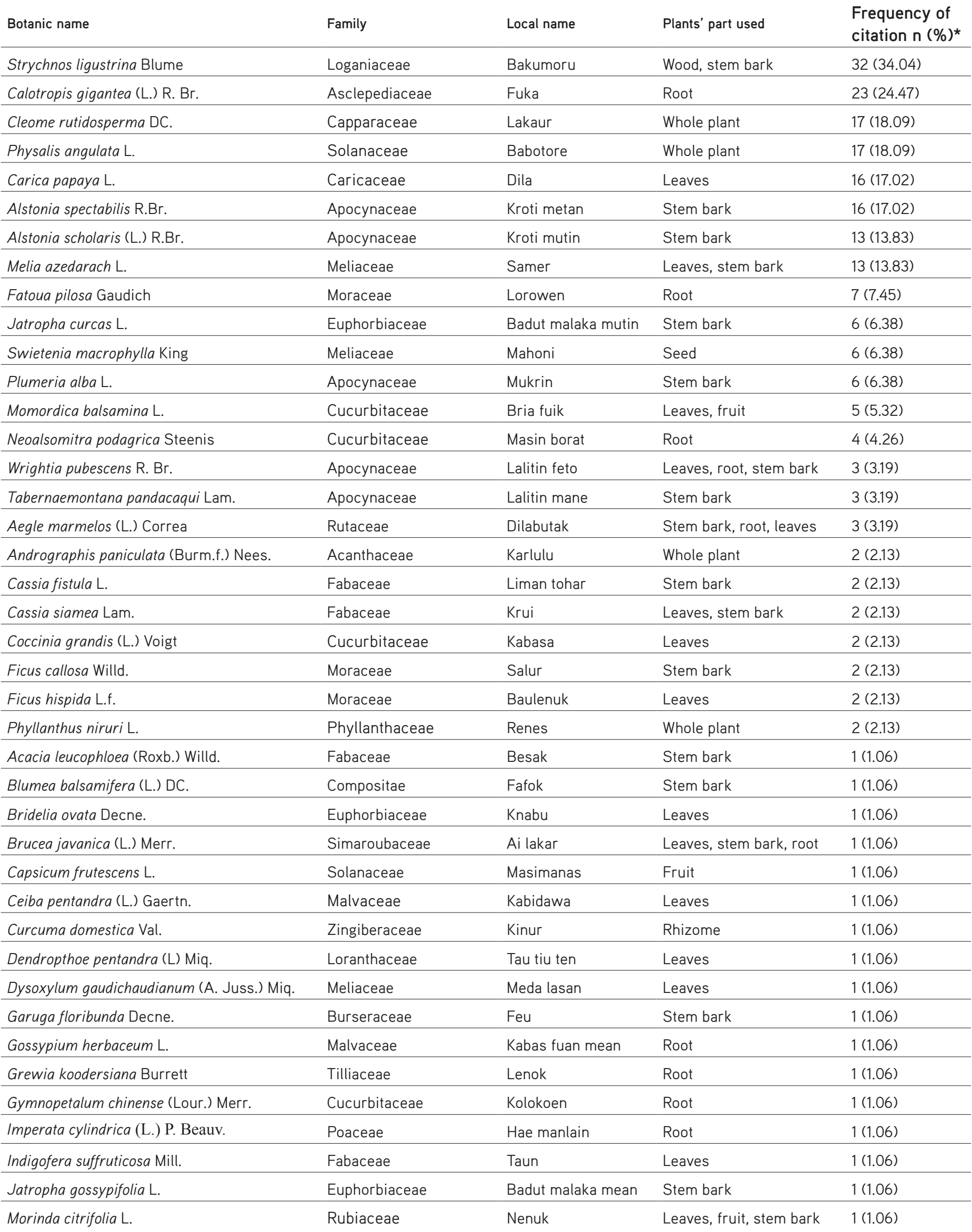


Table 1 continue

\begin{tabular}{lllll} 
Nauclea orientalis (L.) L. & Rubiaceae & Kafiru & Stem bark & 1(1.06) \\
\hline Piper cubeba L.f. & Piperaceae & Kunus aleten & Leaves & 1(1.06) \\
\hline Sterculia foetida L. & Sterculiaceae & Abano & Stem bark & 1(1.06) \\
\hline Tamarindus indica L. & Fabaceae & Sukaer & Leaves & Root \\
\hline Uvaria rufa Blume & Annonaceae & Koke & Stem bark & 1(1.06) \\
\hline Wendlandia burkillii Cowan & Rubiaceae & Katimun & Leaves & 1(1.06) \\
\hline Ziziphus timoriensis DC. & Rhamnaceae & Ai sisi & Leaves & 1(1.06) \\
\hline Not identified & Not identified & Moat tiris & Tuber & 1(1.06)
\end{tabular}

*: The total percentage is greater than $100 \%$ because each informant $(\mathrm{N}=94)$ mentioned more than one plant

C. papaya L. (17.02\%), S. macrophylla King (6.38\%), and M. balsamina L. (5.32\%) were three other plants with high citation frequency but were not included antiplasmodial activity testing because of several reasons. The C. papaya was not selected testing for the reason that it is a food plant that is consumed every day as a vegetable. The wild bitter melon M. balsamina was also not included because it was difficult to obtain, very rarely cultivated, usually only grow wild, and is seasonal. The S. macrophylla was excluded because according to the informants, the use of its seeds as an antimalarial medicine was not sourced from traditional practice of the Tetun people's ancestors.

\section{Antiplasmodial activity}

A graphical comparison of the extracts' ability to inhibit Plasmodium growth is shown in Figure 1. It can be seen from this graph that with an increase in concentration, three extracts, $P$. angulata L., J. curcas L., and $A$. spectabilis R. Br. show a more significant increase in their inhibitory activity compared with the other extracts. The graph presents that on average, a tenfold increase in the concentration of these three extracts increases their antiplasmodial activity twice.

Table 2 lists the antiplasmodial activity of each extract in the form of percentage of inhibition at each concentration level and their $\mathrm{IC}_{50}$ values. The concentration that causes $50 \%$ reduction in Plasmodium growth is represented by $I_{50}$. A smaller $I_{50}$ value indicates the better the extract's antiplasmodial activity; and vice versa, greater $I C_{50}$ indicates low inhibitory activity. In the positive control, with the same experimental condition, chloroquine diphosphate has an $\mathrm{IC}_{50}$ value of $0.005 \mu \mathrm{g} / \mathrm{mL}$.

Ouattara et al. ${ }^{12}$ categorized an extract as very active or strong antiplasmodial if $\mathrm{IC}_{50}<5 \mu \mathrm{g} / \mathrm{mL}$, active or moderate antiplasmodial if $\mathrm{IC}_{50}: 5-50 \mu \mathrm{g} / \mathrm{mL}$, less active or weak antiplasmodial if $\mathrm{IC}_{50}: 50$ $100 \mu \mathrm{g} / \mathrm{mL}$, and inactive if $I_{50}>100 \mu \mathrm{g} / \mathrm{mL}$. Based on these categories, ethanolic extracts of $P$. angulata $\mathrm{L}$. $\left(\mathrm{IC}_{50} 0.22 \mu \mathrm{g} /\right.$ $\mathrm{mL}$ ), J. curcas L. (IC $0.22 \mu \mathrm{g} / \mathrm{mL})$, and $A$. spectabilis $\mathrm{R}$. Br. $\left(I_{50}\right.$ $1.23 \mu \mathrm{g} / \mathrm{mL}$ ) are strong antiplasmodials; whereas $N$. podagrica Steenis $\left(\mathrm{IC}_{50} 11.60 \mu \mathrm{g} / \mathrm{mL}\right)$, A. scholaris (L.) R. Br. (IC $5015.46 \mu \mathrm{g} /$ $\mathrm{mL}$ ), F. pilosa Gaudich. $\left(\mathrm{IC}_{50} 24.92 \mu \mathrm{g} / \mathrm{mL}\right)$, and $P$. alba L. $\left(\mathrm{IC}_{50}\right.$ $36.39 \mu \mathrm{g} / \mathrm{mL}$ ) are moderates. The extracts of C. rutidosperma DC. $\left(I_{50} 54.25 \mu \mathrm{g} / \mathrm{mL}\right), M$. azedarach L. $\left(I_{50} 63.52 \mu \mathrm{g} / \mathrm{mL}\right)$,

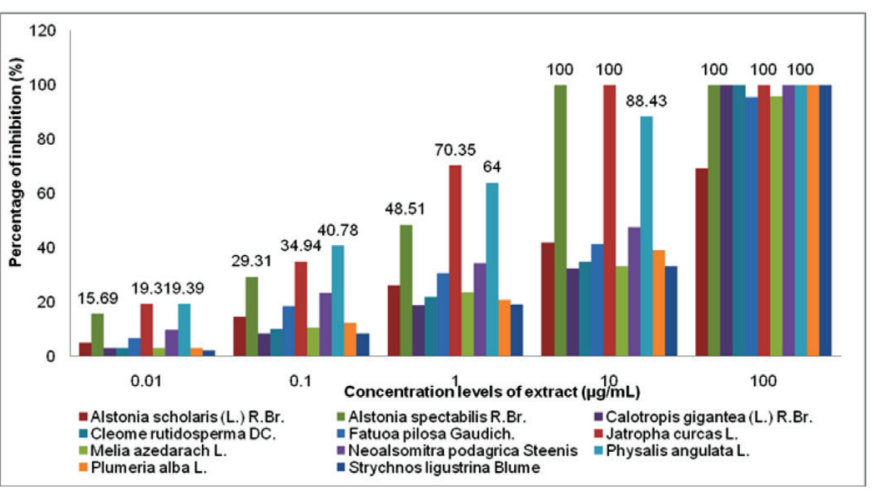

Figure 1. Graphical comparison of the plant extract's inhibitory ability on Pasmodium falciparum 3D7 strain in vitro

S. ligustrina Blume (IC $63.91 \mu \mathrm{g} / \mathrm{mL})$, and C. gigantea (L.) R. Br. (IC $66.49 \mu \mathrm{g} / \mathrm{mL}$ ) are weak antiplasmodial. In general, although they are relatively weaker than chloroquine diphosphates, $P$. angulata L., J. curcas L., and $A$. spectabilis R. Br. ethanolic extracts showed good antiplasmodial effects on $P$. falciparum 3D7 strain.

Among the 11 plant extracts, $P$. angulata $L$. showed the strongest antiplasmodial activity. This result is in line with the findings of previous studies using methanol and dichloromethane extracts of $P$. angulata $L$. leaves, where these extracts presented very high activity with $\mathrm{IC}_{50}<3 \mu \mathrm{g} / \mathrm{mL}$ against the chloroquine-sensitive $3 \mathrm{D} 7$ and chloroquine-resistant W2 strains of $P$. falciparum in vitro. $P$. angulata extracts also showed good in vivo parasitemia inhibition on mice infected by Plasmodium berghei. ${ }^{13}$

In this study, the ethanolic extract of $J$. curcas L. stem bark showed strong antiplasmodial activity, equivalent to $P$. angulata $L$. In another study, it was found that mice infected by $P$. berghei treated with 250,500, and $750 \mathrm{mg} / \mathrm{kg}$ body weight doses of aqueous extract of $J$. curcas L. stem bark decreases parasitemia percentage from $9.25 \%$ to $7.80 \%$, suggesting that the plant extract possesses antiplasmodial properties. ${ }^{14}$

Results in this study showed that ethanolic extract of $P$. alba L. stem bark is a moderate antiplasmodial. Another study showed that water extract $(300 \mathrm{mg} / \mathrm{kg}$ body weight) and dichloromethane-methanol extract ( $300 \mathrm{mg} / \mathrm{kg}$ body weight) of this plant's stem bark reduces parasitemia level of mice 
Table 2. Antiplasmodial activity of plant extracts

\begin{tabular}{|c|c|c|c|c|c|c|}
\hline \multirow{2}{*}{ Plant extract } & \multicolumn{5}{|c|}{$\begin{array}{l}\text { Inhibition percentage of extract on Plasmodium (\%) at each level of } \\
\text { concentration }(\mu \mathrm{g} / \mathrm{mL})\end{array}$} & \multirow[t]{2}{*}{$\begin{array}{l}\mathrm{IC}_{50} \\
(\mu \mathrm{g} / \mathrm{mL})\end{array}$} \\
\hline & 0.01 & 0.1 & 1.0 & 10 & 100 & \\
\hline Alstonia scholaris (L.) R. Br. & 5.06 & 14.52 & 26.20 & 41.89 & 69.26 & 15.46 \\
\hline Alstonia spectabilis R. Br. & 15.69 & 29.31 & 48.51 & 100.00 & 100.00 & 1.23 \\
\hline Calotropis gigantea (L.) R. Br. & 2.96 & 8.43 & 18.96 & 32.44 & 100.00 & 66.49 \\
\hline Cleome rutidosperma DC. & 3.04 & 10.25 & 22.09 & 34.96 & 100.00 & 54.25 \\
\hline Fatuoa pilosa Gaudich & 6.70 & 18.69 & 30.78 & 41.39 & 95.56 & 24.92 \\
\hline Jatropha curcas L. & 19.30 & 34.94 & 70.35 & 100.00 & 100.00 & 0.22 \\
\hline Melia azedarach L. & 2.96 & 10.78 & 23.74 & 33.22 & 95.91 & 63.52 \\
\hline Neoalsomitra podagrica Steenis & 9.74 & 23.39 & 34.26 & 47.74 & 100.00 & 11.60 \\
\hline Physalis angulata L. & 19.39 & 40.78 & 64.00 & 88.43 & 100.00 & 0.22 \\
\hline Plumeria alba L. & 2.98 & 12.45 & 20.88 & 39.04 & 100.00 & 36.39 \\
\hline Strychnos ligustrina Blume & 2.20 & 8.56 & 19.19 & 33.33 & 100.00 & 63.91 \\
\hline
\end{tabular}

infected by $P$. berghei to $16.4 \%$ and $20.0 \%$, respectively, in eight days of evaluation. ${ }^{15}$

Although the ethanolic extract of $A$. scholaris (L.) R. Br. stem bark in this study showed a moderate activity, the results in another study showed that methanolic extract of its stem bark showed excellent antiplasmodial activity against $P$. falciparum 3D7 strain, with a mean $\mathrm{IC}_{50}$ of $0.1650 \pm 0.1100 \mu \mathrm{g} / \mathrm{mL}$. $^{16}$ The stem bark of $A$. scholaris (L.) R. Br. contains villalstonine and macrocarpamine alkaloids, which are antimalarial active, with the $\mathrm{IC}_{50}$ values of 0.27 and $0.36 \mu \mathrm{M}$, respectively, against chloroquine-resistant $P$. falciparum K1 strain. ${ }^{17}$

Ethanolic extracts of S. ligustrina Blume, C. gigantea (L.) R. Br., C. rutidosperma DC., and M. azedarach L. in this study showed weak activity against $P$. falciparum 3D7 strain, with $I_{50}>50 \mu \mathrm{g} /$ $\mathrm{mL}$. However, it was found in several other studies that these plants showed a good antiplasmodial activity when different solvents were used for extraction. Water extract of S. ligustrina Blume wood was classified as a strong antiplasmodial as it inhibited $P$. falciparum growth in vitro by $98.1 \%$ at a concentration of $1.0 \mathrm{mg} / \mathrm{mL} .{ }^{18}$ Methanolic extract of $C$. gigantea (L.) R. Br. leaves showed moderate antimalarial activity against $P$. falciparum in vitro with an $\mathrm{IC}_{50}$ value of $12.17 \mu \mathrm{g} / \mathrm{mL}$, and very good activity against $P$. berghei in vivo. ${ }^{19}$ Ethanolic extract of $C$. rutidosperma DC. whole plant showed moderate antimalarial activity with $I C_{50}$ of $34.4 \mu \mathrm{g} / \mathrm{mL}$; however, its water extract was less active with $\mathrm{IC}_{50}>100 \mu \mathrm{g} / \mathrm{mL}$ against chloroquine-sensitive $P$. falciparum D10 strain in vitro. ${ }^{20}$

The results of this antimalarial activity evaluation did not linear to rank of the plants based on their percentage of citation listed in Table 1. In laboratory testing, the informants' most frequently mentioned plants, which are the S. ligustrina Blume, C. gigantea (L.) R. Br., and C. rutidosperma DC., turned out to show weak antiplasmodial activity. However, it does not mean that these plants' effectiveness claims as antimalarials are incorrect. Possible causes of non-synchronous data between frequency of citation of the informants and the laboratory antiplasmodial evaluation of these plants can be explained as follows. Firstly, the use of ethanol as an extraction solvent can cause differences in type and amount of antiplasmodial active compounds extracted into it, which causes differences in the antiplasmodial activity shown by each plant extract. Secondly, the in vitro system is very different from the biochemical system in the human body, therefore, in vitro antimalarial activity results cannot directly describe the actual events in human body. Therefore, it is possible for an antimalarial plant to be active in human and be inactive in an in vitro testing, and vice versa. Thirdly, certain plants may not be true antimalarial (antiplasmodial) that works to kill or inhibit Plasmodium growth. It may more likely be an indirect antimalarial (antipyretic, analgesic or antiinflammatory) that works to heal malaria-related symptoms, and therefore, the test showed no significant activity as antiplasmodial. As is known, traditional treatment of malaria is a symptomatic healing, which mainly aims to reduce heat or fever; therefore, it is possible that a plant used in this treatment is more likely antipyretic than antiplasmodial.21,22 Plants having antimalarial properties can show a direct effect on Plasmodium by inhibiting growth or killing it; or indirect effects on the relationship between parasites and the human body. A plant that inhibits or kills Plasmodium is called antiplasmodial or true antimalarial. Other plants may serve as indirect antimalarial, which affects the relationship between the human body as a host and Plasmodium, for example as immunostimulant or antipyretic, or causing hemolysis and membrane structure changes, which inhibits Plasmodium growth. ${ }^{23}$

This report of antiplasmodial activity of $N$. podagrica Steenis and $F$. pilosa Gaudich. against $P$. falciparum 3D7 strain is the first based on our search of previous studies in any publications. A study on the antimalarial activity of these two plants was not carried out by other researchers before. The F. pilosa Gaudich. was only reported to have pharmacological activity as an antimycobacterial, ${ }^{24}$ whereas $N$. podagrica Steenis had no known pharmacological activities. Therefore, it is an open 
chance to make further evaluation on the antimalarial activity of these two plants, and to identify their antimalarial active compound(s).

Phytochemicals content of the extracts

Table 3 shows the phytochemical analysis results using GCMS. It can be seen in this table that, overall, these 11 extracts contain various types of natural products, such as alkaloids, terpenoids, steroids, coumarins, alcohols, thiols, phenolics, aldehydes, fatty acids, esters, and so forth. Several studies showed that many secondary plant metabolites, such as alkaloid, flavonoid, xantone, quassinoid, triterpene, and sesquiterpene, have antiplasmodial activity; thus, having the potential to be developed as antimalarial. 4,17

Although identifying the types and amounts of compounds by GC-MS is limited to volatile compounds, results showed each of the extracts contained quite a number of previously unknown compounds; for example, the alkaloid brucine in M. azedarach $\mathrm{L}$ leaves. Some of the compounds identified from the 11 plant extracts, such as alstonine, alstomacroline, pleiocarpamine, lupeol, amyrin, and brucine, are known to have antiplasmodial activity. $13,15,17,25-27$

\section{CONCLUSION}

The Tetun ethnic people use at least 50 plant species as oral antimalarial medicine. The A. scholaris (L.) R. Br., A. spectabilis R. Br., C. gigantea (L.) R. Br., C. rutidosperma DC., F. pilosa Gaudich., J. curcas L., M. azedarach L., N. podagrica Steenis,
P. angulata L., P. alba L., and S. ligustrina Blume are some of the frequently cited plants. These 11 plants have proven to have antiplasmodial activity, ranged from strong to weak antiplasmodial. The P. angulata L., J. curcas L., A. spectabilis R. Br., N. podagrica Steenis, and F. pilosa Gaudich. May have a potential to be developed as new sources of antimalarials.

The novelty of this study is the fact that $N$. podagrica Steenis have never been reported used as antimalarial in other traditional medicine systems elsewhere, and this is the first publication of $N$. podagrica Steenis and F. pilosa Gaudich.'s antiplasmodial activity against the $P$. falciparum 3D7 strain.

\section{ACKNOWLEDGEMENTS}

This study was supported by The Directorate of Research and Community Service, Ministry of Research, Technology and Higher Education, Republic of Indonesia (Research Contract no: 0668/K8/KM/2018), Father Rector of Widya Mandira Catholic University, and Head of Yayasan Pendidikan Katolik Arnoldus Kupang. Thanks to all the informants for their participation in our field study in Belu and Malaka Districts, and to the analyst of Malaria Laboratory, Institute of Tropical Diseases, Airlangga University, for her assistance in the examination of antiplasmodial activity.

Conflicts of interest: No conflict of interest was declared by the authors. The authors alone are responsible for the content and writing of the paper. 
Table 3. Phytochemical contents of the plants'extracts identified using gas chromatography-mass spectrometry

Plant's extrac

Ret-time (min) Compound

Area

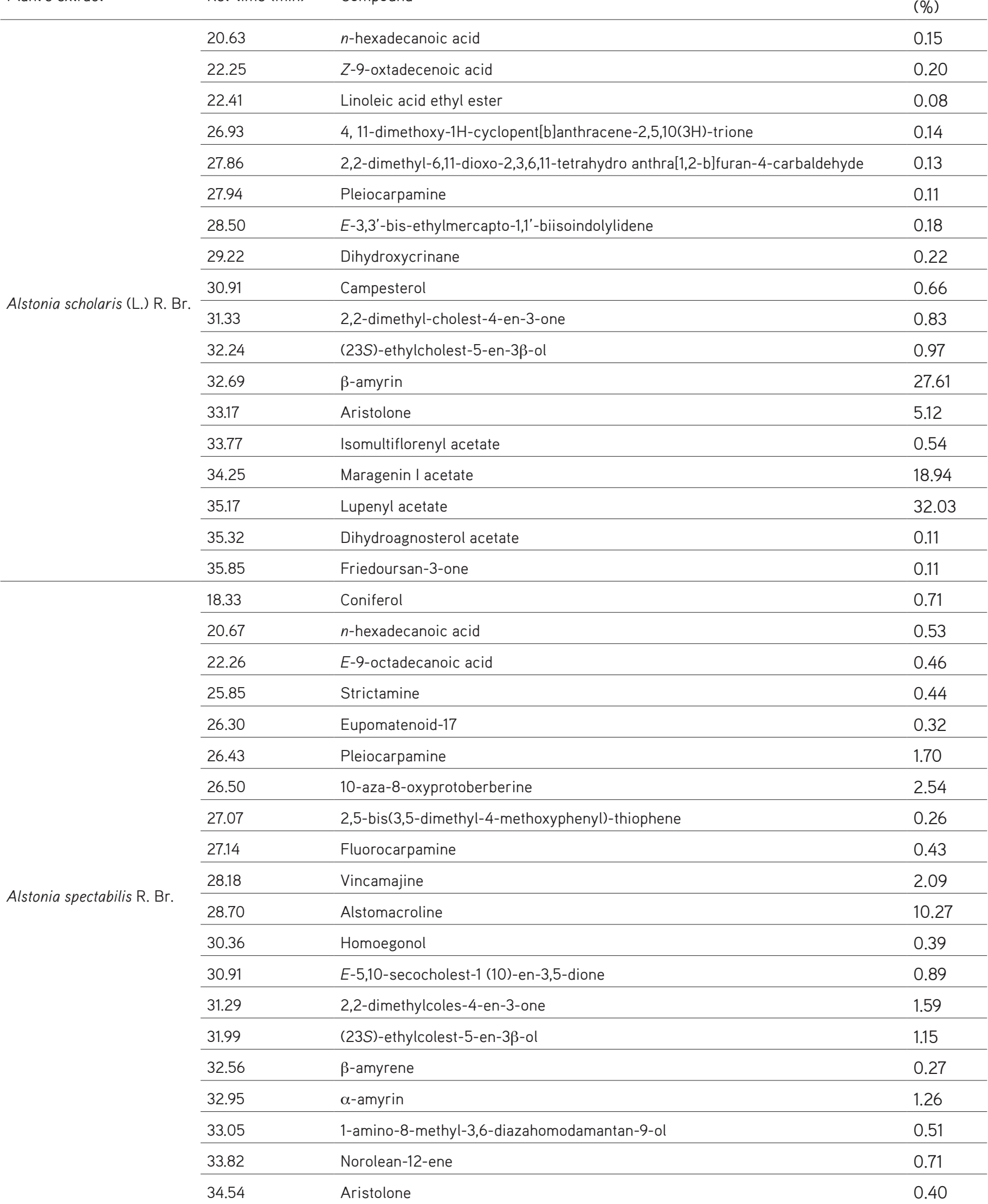


Table 3 continue

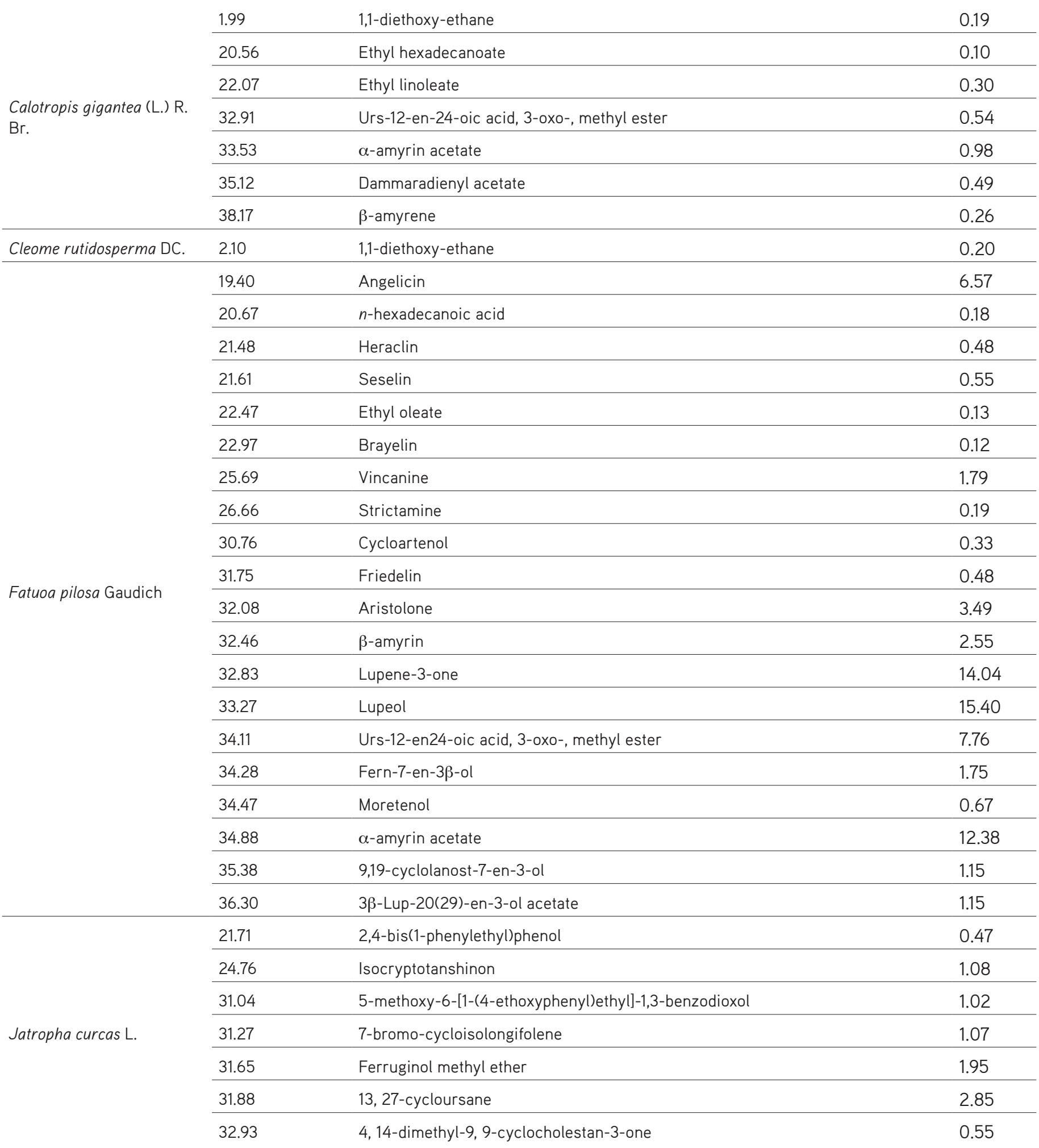


Table 3 continue

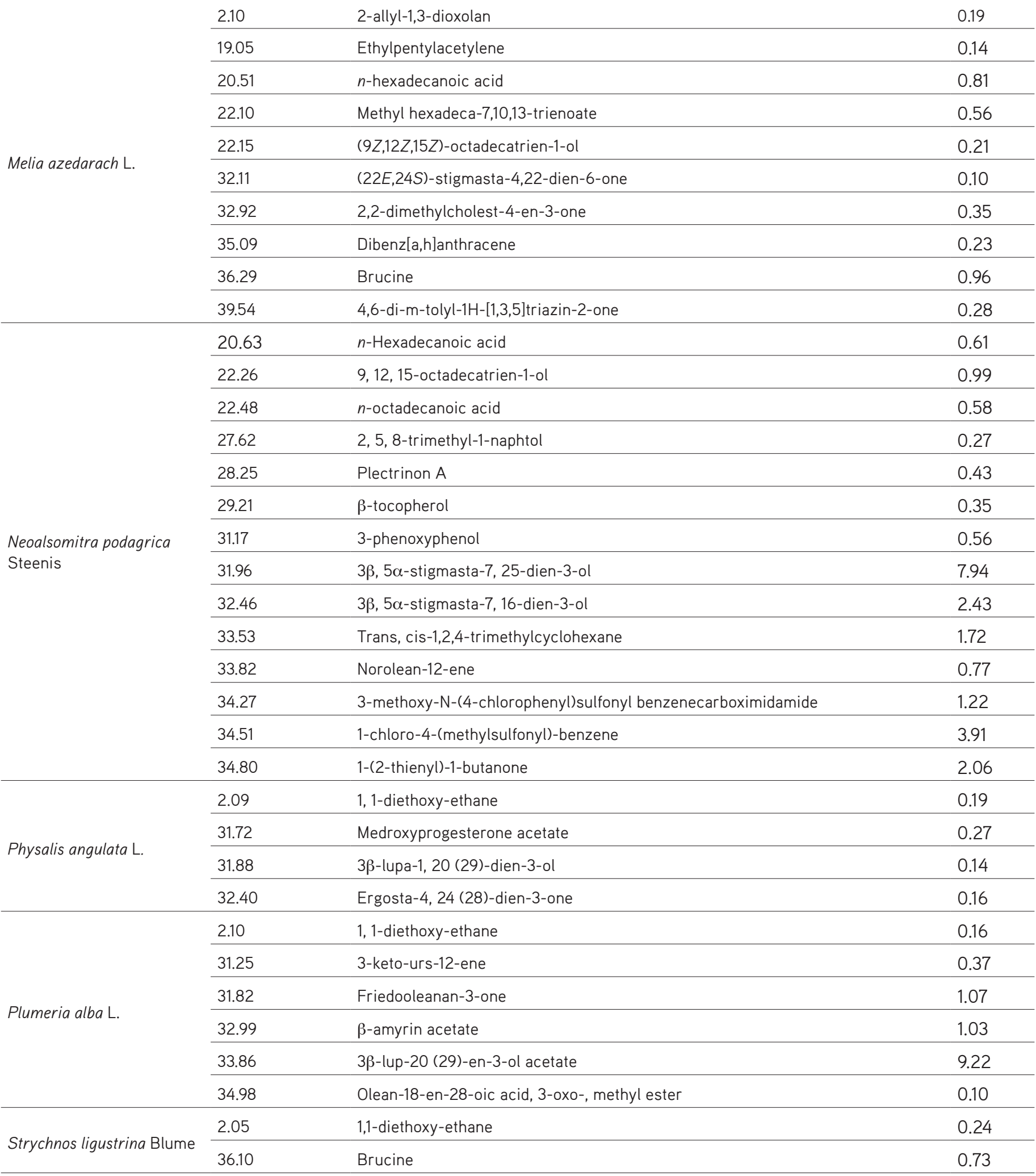




\section{REFERENCES}

1. Verpoorte R. Medicinal plants: A renewable resource for novel leads and drugs. In: Ramawat KG, ed. Herbal drugs: Ethnomedicine to modern medicine. Berlin Heidelberg: Springer-Verlag, 2009.

2. Schippmann U, Leaman DJ, Cunningham AB. Plants as source of medicines: New perspectives. In: Bogers RJ, Craker LE, Lange D, eds. Medicinal and aromatic plants - Agricultural, commercial, ecological, legal, pharmacological and social aspects. Dordrecht: Springer, 2006.

3. Ramawat KG, Goyal S. The Indian herbal drugs scenario in global perspectives. In: Ramawat KG, Merillon JM, eds. Bioactive molecules and medicinal plants. Berlin: Springer, 2008.

4. Schwikkard S, van Heerden F. Antimalarial activity of plant metabolites. Nat Prod Rep. 2002;19:675-692.

5. Htut ZW. Artemisinin resistance in Plasmodium falciparum malaria. N Engl J Med. 2009;361:1807-1808.

6. Akuodor GC, Ajoku GA, Ezeunala MN, Chilaka KC, Asika EC. Antimalarial potential of the ethanolic leaf extract of Pseudocedrala kotschyi. J Acute Dis. 2015;14:23-27.

7. Willcox ML, Bodeker G. Traditional herbal medicines for malaria. Br Med J. 2004;329:1156-1159.

8. Lemma MT, Ahmed AM, Elhady MT, Ngo HT, Vu TL, Sang TK, CamposAlberto E, Sayed A, Mizukami S, Na-Bangchang K, Huy NT, Hirayama K, Karbwang J. Parasitol Int. 2017;66:713-720.

9. Taek MM, Prajogo BEW, Agil M. Plants used in traditional medicine for treatment of malaria by Tetun ethnic people in West Timor Indonesia. Asian Pac J Trop Med. 2018;11:630-637.

10. Drees EM. List of Tree and Shrub Names from Timor. Bogor: Balai Penyelidikan Kehutanan, 1950.

11. Trager W, Jenssen JB. Human malaria parasites in continuous culture. Science. 1976;193:673-675.

12. Ouattara Y, Sanon S, Traor Ã Y, Mahiou V, Azas N, Sawadogo L. Antimalarial activity of Swartzia madagascariensis Desv. (Leguminosae), Combretum glutinosum Guill. \& Perr. (Combretaceae) and Tinospora bakis Miers. (Menispermaceae), Burkina Faso medicinal plants. Afr Trad CAM. 2006;3:75-81.

13. Lusakibanza M, Mesia G, Tona G, Karemere S, Lukuka A, Tits M, Angenot $\mathrm{L}$, Frédérich M. In vitro and in vivo antimalarial and cytotoxic activity of five plants used in Congolese traditional medicine. J Ethnopharmacol. 2010;129:398-402.

14. Sarkiyayi S, Zailani HA, Simon JG. Effects of aqueous stem bark extract of Jatropha curcas on some biochemical indices of mice infected with Plasmodium berghei. Am J Biochem. 2016;6:130-135.
15. Johnson NB, Ameyaw EO, Kyei S, Aboagye B, Asare K, Afoakwah R, Boye $A$, Donfack JH. In vivo antimalarial activity of stem bark extracts of Plumeria alba against Plasmodium berghei in imprinting control region mice. Rep Parasitol. 2013;3:19-25.

16. Abdillah S, Tambunan RM, Farida Y, Sandhiutami NMD, Dewi RM. Phytochemical screening and antimalarial activity of some plants traditionally used in Indonesia. Asian Pac J Trop Dis. 2015;5:454-457.

17. Saxena S, Pant N, Jain DC, Bhakuni RS. Antimalarial agents from plant sources. Curr Sci. 2003;85:1314-1326.

18. Murnigsih T, Subeki, Matsuura H, Takahashi K, Yamasaki M, Yamato O, Maede Y, Katakura K, Suzuki M, Kobayashi S, Chairul, Yoshihara T. Evaluation of the inhibitory activities of the extracts of Indonesian traditional medicinal plants against Plasmodium falciparum and Babesia gibsoni. J Vet Med Sci. 2005;67:829-831.

19. Chan EW, Wong SK, Chan HT. Apocynaceae species with antiproliferative and/or antiplasmodial properties: A review of ten genera. J Integr Med. 2016;14:269-284.

20. Bose A, Smith PJ, Lategan CA, Gupta JK, Si S. Studies on in vitro antiplasmodial activity of Cleome rutidosperma. Acta Pol Pharm. 2010;67:315-318.

21. Taek MM, Prajogo BEW, Agil M. Ethnomedicinal plants used for the treatment of malaria in Malaka, West Timor. J Young Pharm. 2018;10:187192.

22. Taek MM, Prajogo BEW, Agil M. Ethnomedicine of Tetun ethnic people in West Timor Indonesia: Philosophy and practice in the treatment of malaria. Integr Med Res. 2019;8:139-144.

23. Mambu L, Grellier P. Antimalarial compounds from traditionally used medicinal plants. In: Colegate SM, Molyneux RJ, eds. Bioactive natural products: Detection, isolation and structural determination $2^{\text {nd }}$ edition. New York: CRC Press; 2007.

24. Chiang CC, Cheng MJ, Peng CF, Huang HY, Chen IS. A novel dimeric coumarin analog and antimycobacterial constituents from Fatoua pilosa. Chem Biodivers. 2010;7:1728-1736.

25. Widyastuti Y, Adi MBS, Widodo H, Widayat T, Subositi D, Supriyati N, Haryanti S, Damayanti A, Hidayat T. 100 top tanaman obat Indonesia. Cakarta; Kemenkes RI; 2011.

26. Abiodun O, Gbotosho G, Ajaiyeoba E, Happi T, Falade M, Wittlin S, Sowunmi A, Brun R, Oduola A. In vitro antiplasmodial activity and toxicity assessment of some plants from Nigerian ethnomedicine. Pharm Biol. 2011;49:9-14.

27. Sura J, Sumeet D, Raghvendra D. Pharmacological, phytochemical, and traditional uses of Plumeria alba L. an Indian medicinal plant. SPER J Anal \& Drug Reg. 2016:14-17. 